\title{
AKTIVITAS ANTIBAKTERI EKSTRAK ETANOL BAWANG TIWAI (Eleutherine americana Merr.) TERHADAP BAKTERI Staphylococcus aureus DAN Eescherichia coli
}

\author{
Ali istiansyah*, Dewi Rahmawati, Arsyik Ibrahim \\ Laboratorium Penelitian dan Pengembangan FARMAKA TROPIS \\ Fakultas Farmasi Universitas Mulawarman, Samarinda, Kalimantan Timur \\ *Email: Istiansyahali@yahoo.com
}

\begin{abstract}
ABSTRAK
Penelitian ini menggunakan bawang tiwai yang memiliki aktivitas empiris sebagai antimikroba. Penelitian ini bertujuan menentukan rendemen, aktivitas ekstrak etanol dan penentuan konsentrasi efektif ekstrak bawang tiwai terhadap bakteri Staphylococcus aureus dan Eschrichia coli . Metode penelitian ini meliputi ektraksi, pengujian aktivitas dengan konsentrasi $0,5 \%, 1 \%, 2 \%, 4 \%, 8 \%, 12 \%$ menggunakan metode agar cawan. Hasil penelitian ini menghasilkan rendemen ekstrak bawang tiwai sebesar 6,72 \% , aktivitas ekstrak terhadap bakteri Staphylococcus aureus dan Eschrichia coli pada konsentrasi $0,5 \%, 1 \%, 2 \%, 4 \%, 8 \%, 12 \%$ dan konsentrasi efektif adalah $12 \%$ terhadap kedua bakteri uji.
\end{abstract}

Kata Kunci : Bawang tiwai, Aktivitas, Staphylococcus aureus , Eschrichia coli

\begin{abstract}
This study uses bawang tiwai that have empirical antimicrobial activity. This study aims to determine the yield, the activity of ethanol extract and determining the concentration of garlic extract bawang tiwai effective against Staphylococcus aureus and Eschrichia coli. The research methods include extraction, testing activities with a concentration of $0.5 \%$, $1 \%, 2 \%, 4 \%, 8 \%, 12 \%$ use the method to the cup. The results of this study resulted in the yield of bawang tiwai extarct by $6.72 \%$, the activity of the extract against Staphylococcus aureus and Eschrichia coli at a concentration of 0.5\%, 1\%, 2\%, 4\%, 8\%, 12\% and is $12 \%$ effective concentration against both bacteria test.
\end{abstract}

Keyword: Bawang tiwai, Activity, Echericia coli, Staphylococcus aureus

\section{PENDAHULUAN}

Bawang dayak (Eluetherine americana L Merr) merupakan tanaman yang secara empiris banyak digunakan untuk pengobatan. Tanaman ini banyak terdapat di daerah Kalimantan, secara turun temurun dipergunakan masyarakat dayak sebagai tanaman obat., bagian yang digunakan dan di manfaatkan pada bawang bawang dayak adalah umbinya yang berwarna merah terang (Firdaus,2006)

Alia (2011), hasil penelitian sebelumnya yang dilakukan di institute pertanian bogor menunjukan bahwa umbi bawang dayak mengandung senyawa naphtoquinonens dan turunan seperti elecanacine, eleutherin, eleutherol, eleutherone, dimana senyawa Naphtoquinones dikenal sebagai sebagai senyawa antimikroba, antifungal, antiviral, dan antipiretik, selain itu naphtoquinones memiliki bioaktivitas sebagai antikanker dan antioksidan yang biasanya terdapat di dalam sel vakuola dalam bentuk glikosida 
Penelitian ini bertujuan untuk mengetahui rendemen ekstrak bawang dayak (Eluetherine americana L Merr) mengetahuin aktivitas ekstrak bawang tiwai (Eluetherine americana L Merr), mengetahui dan penentuan konsentrasi efektif ektrak bawang tiwai terhadap bakteri Staphylococus aureus dan Eschrichia coli.

\section{METODE PENELITIAN}

\section{Bahan}

Bawang tiwai Alkohol 70\% Aluminium foil Aquades steril Etanol 80\% Kapas Medium Nutrient Agar (NA) $\mathrm{NaCl}$ 0,9\%

\section{Peralatan}

Autoclave Batang pengaduk Erlenmeyer $100 \mathrm{~mL}, 250 \mathrm{~mL}$ dan $500 \mathrm{ml}$ Gelas kimia $100 \mathrm{ml}$ Hot plate Inkubator Laminar Air Flow (LAF) Lemari pendingin Ose bulat Paper disk Pembakar Bunsen Rak tabung reaksi Sendok tanduk Spoid $5 \mathrm{ml} ; 12 \mathrm{ml}$ Tabung reaksi Timbangan analitik

\section{Penyiapan Sampel}

Sampel yang digunakan dalam penelitian ini adalah umbi bawang tiwai yang terlebih dahulu dikeringkan kemudian diambil sebanyak $3 \mathrm{~kg}$ dan siap untuk diekstraksi.

\section{Pembuatan Ekstrak Etanol Umbi Bawang Tiwai}

Pembuatan ekstrak dilakukan dengan mengekstraksi sampel secara maserasi menggunakan pelarut etanol $80 \%$. Sampel umbi bawang tiwai $1 \mathrm{~kg}$ dimasukkan ke dalam wadah toples kaca, lalu ditambahkan pelarut etanol $80 \%$ hingga sampel terendam seluruhnya dan diaduk. Wadah kemudian ditutup dan dibiarkan selama 3 hari sambil sesekali diaduk setiap 24 jam. Hasil ekstraksi kemudian disaring menggunakan kertas saring sehingga diperoleh filtrat dan residunya. Residu penyaringan dimaserasi kembali (remaserasi) hingga filtrat menjadi bening. Filtrat diuapkan menggunakan rotary evaporator pada suhu $55^{\circ} \mathrm{C}$ hingga diperoleh ekstrak kental. Ekstrak kental kemudian diuapkan pada suhu kamar hingga seluruh sisa pelarut menguap dan diperoleh ekstrak kering umbi bawang tiwai.

\section{Regenerasi Bakteri}

Sebelum dipakai dalam uji antibakteri, bakteri yangakan dipakai setiap kali harus diregenerasi terlebih dahulu. Yang pertama dilakukan adalah membuat biakan agar miring yaitu menggoreskan biakan dari stok bakteri ke agar miring yang masih baru. Kemudian diinkubasi $37{ }^{\circ} \mathrm{C}$ selama 24 jam. Jadi biakan tersebut merupakan aktivitas awal dari stok bakteri yang telah disimpan pada suhu $4-5^{\circ} \mathrm{C}$.

\section{Penentuan Konsentrasi Hambat Tumbuh Minimum (KHTM)}

Sampel umbi bawang tiwai yang digunakan adalah hasil dari ekstrak kental yang telah dikeringkan . Dari ekstrak tersebut ditimbang $3.6 \mathrm{~g}$, kemudian dilarutkan dalam 25 $\mathrm{mL}$ aquadest . Campuran ekstrak umbi bawang tiwai tersebut diencerkan sehingga diperoleh konsentrasi yang bervariasi, yaitu $0.5 \%, 1 \%, 2 \%, 4 \%, 8 \%$ dan $12 \%$ ekstrak umbi bawang inilah yang akan diuji aktivitasnya menggunakan metode cakram kertas pada media padat yang telah diinokulasi dengan bakteri uji. Kertas saring dibasahi dengan masing-masing sampel tersebut selanjutnya diukur zona bening yang terbentuk setelah diinkubasi pada suhu $37{ }^{\circ} \mathrm{C}$ selama 24 jam. Zona hambat yang terkecil menunjukkan adanya aktivitas antibakteri yang rendah, sedangkan zona hambat yang besar menunjukkan semakin besar aktivitas antibakterinya. 


\section{HASIL DAN PEMBAHASAN}

\section{Rendemen Ekstrak Etanol Umbi Bawang Tiwai}

Ekstrak adalah sediaan kering, kental, atau cair dibuat dari simplisia nabati atau simplisia hewani yang diolah dengan cara yang tepat diluar pengaruh cahaya matahari langsung (Depkes RI., 1979). Sedangkan rendemen adalah perbandingan antara ekstrak yang diperoleh dengan simplisia awal (Depkes, 2000). Ekstrak umbi bawang tiwai diperoleh dengan ekstraksi secara maserasi menggunakan pelarut etanol 80\%. Campuran pelarut etanol-air dengan persentase $80 \%$ sebagai pelarut diketahui lebih baik dalam menarik senyawa-senyawa seperti flavonoid, alkaloid, tanin, dan minyak atsiri dibanding dengan etanol 95\%. Hal ini dikarenakan campuran etanol-air mengakibatkan perubahan polaritas dari pelarut sehingga akan mempengaruhi jumlah dan jenis senyawa kimia yang tersari (Lestari dan Yohanes, 2014). Menurut Sihombing, dkk. (2008) maserasi merupakan metode ekstraksi cara dingin sehingga zat-zat yang terkandung di dalam simplisia relatif lebih aman jika dibandingkan dengan penggunaan ekstraksi cara panas. Data persentase rendemen ekstrak umbi bawang tiwai dapat dilihat pada tabel 1.

Tabel 1. Rendemen Ekstrak umbi bawang tiwai

\begin{tabular}{cc}
\hline Sampel & Jumlah (gram atau \%) \\
\hline Simplisia kering & 1000 gram \\
Ekstrak & 50 gram \\
Persentase rendemen & $6,7 \%$ \\
\hline
\end{tabular}

\section{Penentuan konsentrasi hambat tumbuh minimum (KHTM)}

Tabel 2. Diameter Zona Hambat

\begin{tabular}{ccc}
\hline Konsentrasi/\% & \multicolumn{2}{c}{ Diameter Zona Hambat } \\
\cline { 2 - 3 } & Escherichia coli $(\mathrm{mm})$ & Staphylococus aureus $(\mathrm{mm})$ \\
\hline 0.5 & 12.622 & 15.053 \\
1 & 16.533 & 17.54 \\
2 & 16.823 & 19.069 \\
4 & 19.265 & 20.223 \\
8 & 21.241 & 21.157 \\
12 & 24.163 & 23.441 \\
\hline
\end{tabular}

Penentuan KHTM ekstrak umbi bawang tiwai yang dapat menghambat pertumbuhan bakteri. Penentuaan KHTM ini dilakukan menggunakan filtrat yang sudah dikeringkan. Ekstrak umbi bawang tiwai yang digunakan bervariasi antara $0.5 \%, 1 \%, 2 \%, 4 \%, 8 \%, 12 \%$. Dari tabel 2 konsentrasi $0.5 \%$ merupakan konsentrasi terkecil dari ekstrak umbi bawang tiwai yang dapat menghambat pertumbuhan bakteri Eschrichia coli dan Staphylococus aureus dan $12 \%$ sebagai konsentrasi terbesar. Dengan variasi konsentrasi yang digunakan, aktivitas antibakteri Semakin tinggi konsentrasi, zona hambatan semakin besar

\section{KESIMPULAN}

Jumlah rendemen yang diperoleh dari Ekstrak etanol umbi bawang tiwai (Eleutherine americana Merr.) adalah $6.72 \%$ dengan aktivitas ekstrak terhadap bakteri Staphylococcus aureus dan Eschrichia coli pada konsentrasi 0,5\%,1\%,2\%,4\%,8\%,12\% dan diperoleh konsentrasi efektif adalah $12 \%$ terhadap kedua bakteri uji. 


\section{DAFTAR PUSTAKA}

1. Alia mustika nur 2011. Kapasitas Antioksidan Bawang dayak (Eluetherine palmifolia) dalam Bentuk Segar, Simplisia, dan Kripik, Pada Pelarut Nonpolar, Semipolar dan Polar. Fakultas Teknologi Pertanian Institut Pertanian Bogor.

2. Depkes RI., 1996, Materia Medika Indonesia Jilid VI. Direktorat Jendral Pengawasan Obat dan Makanan. Jakarta.

3. Depkes RI., 1979, Farmakope Indonesia Edisi III. Departemen Kesehatan Republik Indonesia. Jakarta.

4. Depkes RI., 2000, Parameter Standar Umum Ekstrak Tumbuhan Obat. Cetakan Pertama. Departemen Kesehatan Republik Indonesia. Jakarta.

5. Firdaus R.2006. Kandungan Kimia Ekstrak Metanol Umbi Bawang Tiwain (Eluetherine Americana L Merr). Skripsi Institut Teknologi Bandung

6. Lestari, A. B. S., dan Yohanes, D., 2014. Aktivitas Antioksidan Ekstrak Daun Sirih Merah (Piper crocatum $)$ Hasil Optimasi Pelarut Etanol - Air. Jurnal Ilmu Kefarmasian Indonesia. Vol.21. No.1: 75-79.

7. Sihombing, C. N., Nasrul, W., dan Taofik, R., 2008, Formulasi Gel Antioksidan Ekstrak Buah Buncis (Phaseolus vulgaris L.) dengan Menggunakan Basis Aqupec 505 $H V$. Universitas Padjajaran. Bandung 